\title{
HOUSEHOLD EXPENDITURES, WAGES, RENTS
}

\author{
MORRIS A. DAVIS \\ FRANÇOIS ORTALO-MAGNÉ
}

\author{
CESIFO WORKING PAPER NO. 2156 \\ CATEgory 5: Fiscal Policy, MACROECONOMICS AND GROWTH \\ DECEMBER 2007
}
An electronic version of the paper may be downloaded
- from the SSRN website: Www.SSRN.com
- from the RePEc website: $\quad$ www.RePEc.org
- from the CESifo website: www.CESifo-group.org/wp




\title{
HOUSEHOLD EXPENDITURES, WAGES, RENTS
}

\begin{abstract}
We provide new evidence from the 1980, 1990, and 2000 Decennial Census of Housing that the expenditure share on housing is constant over time and across U.S. metropolitan areas (MSA). Consistent with this observation, we consider a basic model in which identical households with Cobb-Douglas preferences for housing and numeraire consumption choose an MSA in which to live and MSAs differ with respect to income earned by residents. We compute constant-quality wages and rental prices for a sample of 50 U.S. MSAs. Given estimated wages, the calibrated model predicts that rental prices should be more dispersed than observed. That is, the model suggests that rental prices are too low in many high-wage MSAs in the year 2000.
\end{abstract}

JEL Code: D10, R21.

Keywords: household expenditures, housing prices, Cobb-Douglas utility.

Morris A. Davis

University of Wisconsin-Madison

Department of Real Estate and

Urban Land Economics

5261 Grainger Hall

975 University Avenue

Madison, WI 53706

USA

mdavis@bus.wisc.edu
François Ortalo-Magné

University of Wisconsin-Madison

Department of Real Estate and

Urban Land Economics

5261 Grainger Hall

975 University Avenue

Madison, WI 53706

USA

fom@bus.wisc.edu

November, 2007

We thank Kenneth Burdett, Tom Davidoff, Andrea Finicelli, Kenneth Kavajecz, Jeremy Lise, Erzo G.J. Luttmer, Benjamin Malin, Stephen Malpezzi, Derek Neal, Andrea Prat, Tim Riddiough, Stijn Van Nieuwerburgh, Randy Verbrugge, Pierre-Olivier Weill and Randall Wright for comments and suggestions. We are also grateful for discussions at the Annual Conference of the North American Regional Science Council and the 2007 Vienna Macroeconomics Workshop, and at seminars at the Federal Reserve Bank of Chicago, Indiana University, Toulouse School of Economics, the University of California at Berkeley, the University of Wisconsin - Madison, and the University of Essex. We thank Leslie McGranahan for her help with the Consumer Expenditure Survey. 


\section{Introduction}

A number of recent papers explore the relationship of housing prices and quantities with aggregate consumption, aggregate investment and asset prices. ${ }^{1}$ A common assumption in this literature is that consumption and housing are complementary in utility, but the assumed elasticity of substitution between housing and consumption varies from paper to paper. ${ }^{2}$ This elasticity is critical to the predictions of macroeconomic and asset pricing models. Among other things, it pins down the steady-state rate of growth of aggregate house prices given the steady-state rate of growth in the quantities of consumption and housing services.

In contrast to the volume of research studying changes to house prices and quantities in the aggregate, there are few recent equilibrium-based studies of the market forces determining the cross-sectional distribution of house prices across cities. ${ }^{3}$ The papers that address this topic tend to be regression-based in nature, and presume that theory dictates that house prices in any MSA should increase at the same rate as average income in that MSA. When incomes and prices do not increase at the same rate, the authors assume something is amiss. Papers in this literature talk of house price "bubbles." 4

In this paper, we contribute to the two streams of literature identified above. We document new evidence characterizing the housing consumption behavior of U.S. households. We then build a model consistent with this evidence and show the model sheds new light on the distribution of housing prices across U.S. metropolitan areas.

Specifically, we begin by showing that the expenditure share on housing has been nearly constant at the aggregate level since 1960. We then use micro data from the last three Decennial Census of Housing (DCH) surveys to document that the housing expenditure share of renting households the only households for which expenditures on rent are directly observable - has been remarkably

\footnotetext{
${ }^{1}$ For papers on housing investment and/or house prices, see Davis and Heathcote (2005, 2007), Fisher (1997, 2007), Gervais (2002), Iacoviello (2005), Gomme et. al. (2001), Greenwood et. al. (1995), Kiyotaki et al. (2007), Krueger and Fernandez-Villaverde (2005), and Li and Yao (2006). Recent work on the role of housing in the pricing of financial assets includes Flavin and Nakagawa (2007), Lustig and Van Nieuwerburgh (2006), Ortalo-Magné and Prat (2007), and Piazzesi et. al. (2007).

${ }^{2}$ For example, Flavin and Nakagawa (2007) and Lustig and Van Nieuwerburgh (2006) argue consumption and housing are more complementary than Cobb-Douglas; Davis and Heathcote (2005) argue for Cobb-Douglas preferences in consumption and housing; and Piazzesi et. al. (2007) argue consumption and housing are more substitutable.

${ }^{3}$ The paper that stimulated our interest in the topic is by Van Nieuwerburgh and Weill (2007). Van Nieuwerburgh and Weill also use an equilibrium model to predict the cross-sectional distribution of house prices. In contrast to our work, they assume households have quasi-linear utility of consumption and housing, and are concerned with quantifying the impact of time-series changes to housing supply restrictions on equilibrium allocations and welfare.

${ }^{4}$ See Case and Shiller (2004) and Malpezzi (1999), for example. This literature continues to expand, even though recently Gallin (2006) finds that local house prices and local incomes are not cointegrated.
} 
constant over time and across U.S. metropolitan areas. In each of the three DCH surveys (1980, 1990, and 2000), our estimate of the housing expenditure share does not vary widely across MSAs despite significant variation in average income. The expenditure share on housing is also remarkably stable over time within each MSA, despite sometimes sizeable changes over time to real rental prices. In summary, in section 2 we make the case for Cobb-Douglas preferences for consumption and housing.

In section 3, we consider the implications of a Cobb-Douglas preference assumption for the equilibrium distribution of house prices across MSAs. We develop a simple multi-location model where identical households costlessly choose an MSA in which to live as well as housing in that MSA and numeraire consumption. MSAs differ with respect to income earned by residents. There is a fixed stock of perfectly divisible housing units in each MSAs. Given our estimate of the expenditure share on housing of 24 percent, we show the difference in log rental prices of two MSAs must equal $4.2(=1 / 0.24)$ times the difference in log per-capita income. Equivalently, if income growth in any MSA outpaces growth in average income (across MSAs) by 1 percentage point, rental prices in that MSA will outpace the average growth in rental prices by 4.2 percentage points. Thus, in a multi-city model where identical households have Cobb-Douglas preferences for housing and consumption, rental prices in an MSA will not, in general, increase at the same rate as income in that MSA.

The economics of this last result are straightforward. In the aggregate, the overall amount of housing and the total population are both independent of where exactly people live. Given the expenditure share on housing in all locations is fixed, it can be shown that average rent per unit of housing in the aggregate increases at the same rate as per-capita aggregate income. In the cross section, in contrast, people are free to move between MSAs, and the allocation of people across MSAs exactly determines housing per person in each city. Expanding on this thought, if households have utility over two items, consumption and housing, and households are free to move between MSAs, then MSAs offering high levels of wages and thus consumption must simultaneously offer low levels of housing, which is accomplished by having a relatively large population. The fact that consumption and housing are complementary in utility means that MSAs with high consumption and low housing will necessarily have relatively high rental prices.

In the last part of our analysis, we use DCH data to compute constant-quality wages and rental prices for the MSAs in our sample. We then calibrate our model and compare model-predicted rental prices for each MSA to data. We show that the model predicts too much dispersion in rental 
prices. That is, the model predicts that rental prices of many high-wage MSAs should be higher than currently observed; this result remains when we correct for variation across MSAs in the price of consumption. Obviously, we have not presented evidence in favor or against the assumption that certain MSAs (for example, San Francisco, CA) are desirable and thus expensive place to live because they have high amenities and a limited supply of housing, as conjectured by Gyourko et. al. (2006) and others. Rather, we just note that these assumptions are not necessary to explain why San Francisco is pricey.

\section{Evidence on Expenditure Shares}

We begin by examining an estimate of the aggregate expenditure share on housing that can be constructed using data from the National Income and Product Accounts (NIPA), as produced by the Bureau of Economic Analysis (BEA). The estimate can be computed as the sum of expenditures on housing services (line 14) and household operation (line 15) divided by total personal consumption expenditures (line 1), data from NIPA table 2.3.5. Expenditures on housing services include both measured rental payments by tenants and an imputation of the rental value of owned homes, and expenditures on household operation include expenditures on electricity, gas, water, telephone. ${ }^{5}$

The expenditure share on housing resulting from this calculation for the 1929-2006 period, the entire period for which annual data are available, is shown in figure 1. The mean of the expenditure share over this period is 20.1 percent with a standard deviation of 2.0 percent. If only the past 46 years experience is considered (1960-2006), the mean of the expenditure share is 21.0 percent and the standard deviation is only 0.6 percent. Given the stable mean and low standard deviation, a reasonable characterization of NIPA data is that the expenditure share on housing is constant. For this reason, recent macroeconomic models studying housing specify Cobb-Douglas preferences for consumption and housing: Examples include Davis and Heathcote (2005), Iacoviello (2005), and Kiyotaki et al. (2007).

For the purposes of establishing the constancy of the expenditure share on housing as a stylized fact, the NIPA-based estimate is potentially problematic because expenditures on space rent by homeowners are imputed. For example, in 2004 the imputed amount for space rent for owneroccupied dwellings accounted for 54 percent of the sum of expenditures on housing services and

\footnotetext{
${ }^{5}$ There are some other miscellaneous components of spending on housing services and household operation. In 2005, these other components accounted for about 8.5 percent of the total.
} 
household operation in the NIPA. ${ }^{6}$ The reason that space rent for owned homes is imputed is that house prices for owner-occupied housing are observed, but market-based rental expenditures on these houses are not.

Verbrugge (2006) and others have argued that expenditures on housing services by homeowners can be imputed as the product of a current mortgage rate and (self-reported) house value. This estimate may not reflect the current rental price of the house because house prices are capitalized rents, and cap-rates vary across locations if either future expected rental growth or the locationspecific risk component of housing assets varies across MSAs. Recent theory (Ortalo-Magné and Prat 2007) and evidence (Campbell et. al. 2007) suggests that the risk-premia for owner-occupied housing could significantly vary across MSAs.

To circumvent the problem that homeowner expenditures on housing services are essentially unobservable, we study the expenditures on housing services by renting households. We construct an estimate of the expenditure share on housing by renting households using micro data from the Decennial Census of Housing (DCH) files. ${ }^{7}$ The first three columns of Table 1 list the median of the ratio of annual gross rent to total household wage and salary income that we derive from the DCH for the top 50 MSAs by population in 2000, for renter households with nonzero wage and salary income and nonzero rental payments, for the years 1980, 1990, and 2000. These MSAs account for about 46 percent of the population in 1980-2000. The total proportion of the population living in this set of MSAs has remained about fixed, although population has shifted among MSAs. Gross rental payments are inclusive of expenditures on utilities, and thus the estimates in Table 1 are likely comparable to the NIPA-based estimate.

The data in Table 1 show that, measured at the median, the estimated expenditure share on housing is remarkably stable across MSAs and over time. ${ }^{8}$ In any given year, the expenditure share, measured at the median, is nearly constant across MSAs at about 0.24 with a standard

\footnotetext{
${ }^{6}$ We do not believe that the BEA is imputing the rental value of owned-homes in such a way as to ensure the constancy of this expenditure share. Available documentation (Personal Consumption Expenditures, 1990, p. 61) suggests that since 1984, the BEA has computed owner-occupied rent as the price index for owner-equivalent rent from the CPI, times a quality adjustment to account for improvements to the owner-occupied stock of housing, times an estimate of the aggregate number of owned housing units.

${ }^{7}$ These data are available at the Integrated Public Use Microdata Series (IPUMS) web site, http://usa.ipums.org/usa/. We exclude farm households, households living in group quarters, and households living in mobile homes, trailers, boats, tents, vans, or "other" from the DCH data.

${ }^{8}$ An estimate of the expenditure share on housing for non-homeowners in the aggregate U.S. can also be computed using the Consumer Expenditure Survey (CEX). From 1980-2005, the CEX-generated estimate has trended up from 0.20 to 0.25 . Although the average of this share is in-line with the estimates in Table 1 , the fact that the CEX estimate has a trend is at odds with our DCH-based evidence that the expenditure share is stable.
} 
deviation of about 0.02 (shown in the bottom two rows). The fact that expenditure shares remain constant over time in each MSA, and constant across MSAs in each year, is not due to lack of cross-sectional variation of income or time-series variation in real rental prices. The fourth column of Table 1 reports, by MSA, the average household wage and salary income in 2000 for renter households with an expenditure share on housing within 1 percentage point of the MSA-median. The standard deviation of this measure, $\$ 5,867$, is 17 percent of the MSA-average, $\$ 35,425$. The right-most column of Table 1 reports growth of real rental prices in each MSA from 1980-2000. ${ }^{9}$ The reported expenditure share in each MSA is nearly constant in every MSA, despite the sometimes large increases in the real relative price of rental units shown in this column.

Although the distribution of expenditure shares of renting households is roughly constant in all MSAs in any given year and across time for any MSA - the average across MSAs of the 25th and 75 percentiles of the expenditure shares are 17 and 36 percent, respectively, and these percentiles are stable across MSAs and over time (not shown $)^{10}$ - one caveat to our findings is that within each MSA, the expenditure share on rent is decreasing with household income in that MSA. One possibility is that expenditures truly fall with income, and that our finding that the median of the expenditure share is nearly constant across time and places is coincidence. We do not share this view, and in the remainder of this section we argue that the negative correlation of income and expenditure shares within MSAs is not necessarily at odds with a constant expenditure share on housing. The reason is that we do not compute an exact measure of expenditure shares, because we divide rental expenditures by wage and salary income and not by consumption, which is unobserved. The gap between consumption and income is key to explaining why expenditure shares fall with income.

To see this, suppose that consumption is equal to permanent income, and that observed income for person $i$ is equal to permanent income for that person, $\bar{w}_{i}$, times a deviation of income from permanent income, $e_{i}$, such that

$$
w_{i}=\bar{w}_{i} e_{i}
$$

For simplicity, assume that the natural $\log$ of $e_{i}$ is Normally distributed with mean 0 and variance $\sigma^{2}$. By assumption, the median of $e_{i}$ is therefore 1 .

\footnotetext{
${ }^{9}$ Growth in real rental prices is computed as growth in nominal rental price per unit less consumer price inflation excluding housing services and household operation. Nominal rent per unit is computed in 1980 and 2000 using DCH data and a hedonic regression approach described later in the paper. Consumer prices less housing services and household operation increased by 84 percent from 1980-2000 according to data from the NIPA.

${ }^{10}$ The standard deviation across MSAs of the expenditure share at the 25th and 75th percentiles is almost exactly 1.6 and 3.5 percentage points, respectively, in each of 1980, 1990, and 2000 .
} 
Now suppose that each person spends a constant fraction of their permanent income on rent, such that

$$
\frac{x_{i}}{\bar{w}_{i}}=\alpha
$$

where $r_{i}$ is the rental expenditure of person $i$. The observed expenditure share is a random variable with a distribution of

$$
\frac{x_{i}}{w_{i}}=\left(\frac{x_{i}}{\bar{w}_{i}}\right)\left(\frac{\bar{w}_{i}}{w_{i}}\right)=\alpha\left(\frac{1}{e_{i}}\right)
$$

When $e_{i}>1$, implying income is higher than permanent income, the observed expenditure share will be less than $\alpha$ and vice-versa. An unbiased estimate of $\alpha$ is the median of equation (3), since the median value of $e_{i}$ is 1 . The fact that $e_{i}$ is assumed to be lognormally distributed is not important; the fact that the median of $e_{i}$ is equal to 1 , however, is critical.

With the assumptions we have made, the distribution of observed expenditure shares is independent of the distribution of permanent income, and only depends on the distribution of the deviation of income from permanent income. If the distribution of the deviations of income from permanent income is similar across MSAs, then the distribution of our estimated expenditure shares will also be similar across MSAs. This may be the reason why the inter-quartile range of the expenditure share is stable across MSAs and over time.

An easy way to show that the distribution of expenditure shares is independent of the distribution of permanent income given the assumptions we have made, is to assume that there are only two levels of permanent income in the sample, $\bar{w}_{i, 1}$ and $\bar{w}_{i, 2}$, and that the probability a person has permanent income equal to $\bar{w}_{i, 1}$ is $p$. If the distribution of deviations is independent of the level of permanent income, then the distribution of expenditure shares is independent of $p, \bar{w}_{i, 1}$, and $\bar{w}_{i, 2}$ :

$$
\begin{aligned}
& p\left(\frac{x_{i, 1}}{w_{i, 1}}\right)+(1-p)\left(\frac{x_{i, 2}}{w_{i, 2}}\right) \\
= & p \alpha\left(\frac{1}{e_{i}}\right)+(1-p) \alpha\left(\frac{1}{e_{i}}\right) \\
= & \alpha\left(\frac{1}{e_{i}}\right) .
\end{aligned}
$$

Thus, the fact that income is not equal to permanent income is sufficient to cause measured expenditure shares to fall with observed income, as they do in the data. In fact, given our assumptions it can be shown that the correlation of the inverse of the expenditure share $\left(w_{i} / x_{i}\right)$ with observed income $w_{i}$ should equal 1 . In our data, the correlation of the inverse of the expenditure share with observed income varies by MSA, but the average is about 0.7 . 
Finally, if deviations of $\left(w_{i} / x_{i}\right)$ from average are truly reflective of differences in current income from permanent income, then we should expect to see $e_{i}$ vary in a particular way with age. Assuming that income over the life-cycle is hump-shaped, with a peak somewhere around age 55, we should expect to find that $e_{i}$ increases with age until peak earnings years, somewhere around age 55, and then declines after that. To test this, we compute deviations of $\log \left(w_{i} / x_{i}\right)$ from its average - these deviations are exactly equal to $\log \left(e_{i}\right)$ - and then regress the deviations on age of the primary wage earner of the household, with age lumped into 5 year bins (except for the bins corresponding to the youngest and oldest ages). The coefficients from these regressions for all three DCH years are shown in Figure 2. The coefficients on each age bin are broadly comparable across years, and the coefficients behave exactly as expected, rising until about age 55 and then declining. ${ }^{11}$

\section{Model with Constant Expenditure Shares}

\subsection{Environment}

We consider an economy with $N$ MSAs indexed by $i=1, \ldots, N$. The economy is populated by a measure $\mu$ of identical agents. The decision problem of agents in this economy is static and thus we suppress time subscripts. Any agent who lives in MSA $i$ produces $w_{i}$ units of food, the numeraire consumption good. There are $H_{i}$ units of divisible housing in MSA $i$ owned by a measure zero of agents who behave competitively in the rental housing market.

Agents choose in which MSA to live, how much food to consume and how much housing to rent. Given a set of housing rental prices for each MSA, $\left\{r_{i}\right\}_{i=1, N}$, agents choose the MSA $i$, food consumption $c$ and housing $h$ that solve the following problem:

$$
\begin{aligned}
\max _{i, c, h} \quad c^{1-\alpha} h^{\alpha} \\
\text { subject to } \quad c+r_{i} h \leq w_{i},
\end{aligned}
$$

with $0<\alpha<1$. All agents who choose the same MSA $i$ choose the same numeraire and housing levels $c_{i}=(1-\alpha) w_{i}$ and $h_{i}=\alpha w_{i} / r_{i}$.

An allocation is fully characterized by the set of food consumption and housing chosen by agents in each MSA, $\left\{c_{i}, h_{i}\right\}_{i=1, N}$ and the measures of agents living in each MSA, $\left\{n_{i}\right\}_{i=1, N}$. An equilibrium in this economy is a set of rental prices $\left\{r_{i}\right\}_{i=1, N}$, and an allocation such that: (1) Agents maximize their utility taking the rental prices as given; (2) In every MSA that is occupied,

\footnotetext{
${ }^{11}$ This evidence is in line with the findings of Fernandez-Villaverde and Krueger (2005).
} 
the housing market clears; i.e., $n_{i} h_{i}=H_{i}$ if $n_{i}>0$.; (3) No household wants to move; i.e., all agents derive the same utility whatever MSA they choose.

We restrict our attention to sets of parameters such that all MSAs are occupied in equilibrium. Rearranging the market clearing conditions and summing over all MSAs yield:

$$
\sum_{i=1}^{N} n_{i}=\sum_{i=1}^{N} H_{i} / h_{i}=\mu .
$$

The condition that agents are indifferent between living in MSAs $i$ and $j$ means:

$$
\left[(1-\alpha) w_{i}\right]^{1-\alpha}\left[h_{i}\right]^{\alpha}=\left[(1-\alpha) w_{j}\right]^{1-\alpha}\left[h_{j}\right]^{\alpha}
$$

where we replace food consumption using the solution to the agents' utility maximization problem. Rearranging, we obtain:

$$
\frac{h_{i}}{h_{j}}=\left(\frac{w_{i}}{w_{j}}\right)^{\frac{\alpha-1}{\alpha}} .
$$

Combining this equation with equation (7) yields the equilibrium housing in each MSA:

$$
h_{i}=\frac{\left(\sum_{j=1}^{N} H_{j} w_{j}^{\frac{1-\alpha}{\alpha}}\right)}{\mu w_{i}^{\frac{1-\alpha}{\alpha}}} .
$$

Plugging this equation into the solution to the agent's optimal housing choice then yields the equilibrium rental prices:

$$
r_{i}=\frac{\mu \alpha w_{i}^{\frac{1}{\alpha}}}{\left(\sum_{j=1}^{N} H_{j} w_{j}^{\frac{1-\alpha}{\alpha}}\right)}
$$

The equilibrium measures of households for each MSA are then trivial to obtain:

$$
n_{i}=\frac{\mu H_{i} w_{i}^{\frac{1-\alpha}{\alpha}}}{\left(\sum_{j=1}^{N} H_{j} w_{j}^{\frac{1-\alpha}{\alpha}}\right)} .
$$

\subsection{Predictions}

The model predicts that the optimal expenditure share on housing is constant at $\alpha$ in every MSA. If we were to include time subscripts, and specify the economy as a sequence of static problems, then the predicted expenditure share on housing would also be constant over time. This result directly follows from our assumption of a Cobb-Douglas utility assumption. 
The more interesting prediction of the model is that the ratio of rental prices between any two MSAs $i$ and $j$ depends only on the ratio of their incomes. Working with equation (11), it is easy to show that

$$
\frac{r_{i}}{r_{j}}=\left(\frac{w_{i}}{w_{j}}\right)^{\frac{1}{\alpha}} .
$$

Equation (13) implies that rental prices in MSA $i$ will not increase at the same rate as income in MSA $i$ if income increases relative to that of MSA $j$. Specifically, if income in MSA $i$ increases by one percentage point more than income in MSA $j$, then rental prices in MSA $i$ will outpace rental prices in $j$ by $1 / \alpha$ percent. If $\alpha=0.24$, as we assume in the next section, then each percentage point differential in wage growth translates to a 4.2 percentage point differential in rental growth.

The intuition behind this result is straightforward. Suppose that $i$ and $j$ are identical in every respect. Now suppose that city $i$ is hit with a positive income shock but income in city $j$ remains constant. In equilibrium, the following condition must hold to ensure that agents are indifferent to living in city $i$ and city $j$ :

$$
c_{i}^{1-\alpha} h_{i}^{\alpha}=c_{j}^{1-\alpha} h_{j}^{\alpha} .
$$

The first-order conditions specify that $c_{i}$ and $r_{i} h_{i}$ both increase with $w_{i}$. For equation (14) to hold, if $c_{i}$ increases, $h_{i}$ must simultaneously decrease. Thus, $h_{i}$ is decreasing at the same time that $r_{i} h_{i}$ is increasing.

Equation (13) also implies that the supply of housing in MSA $i$ or $j$ does not affect relative rental prices in either $i$ or $j$. Thus, according to the model, San Francisco, CA is not expensive relative to, say, Tucson, AZ, because of supply restrictions enacted in San Francisco. Supply does not affect relative prices because households are free to move across MSAs. A particular MSA's own housing supply affects directly the number of agents who live in this MSA. Mathematically, $H_{i}$ enters in $r_{i}$ and $h_{i}$ only through the term $\left(\sum_{j=1}^{N} H_{j} w_{j}^{\frac{\alpha}{1-\alpha}}\right)$, just as the supply of any other MSA. A direct implication of this formula is that changes in the supply of housing in any MSA affects price levels everywhere, but does not affect the relative price of housing of any two MSAs.

Equations (11) and (12) can be combined to show that at the aggregate level, the model produces a constant ratio of rental expenditures to income,

$$
\frac{\sum_{i} r_{i} H_{i}}{\sum_{i} n_{i} w_{i}}=\alpha
$$

The model also predicts that the ratio of average rental price per unit to aggregate per-capita income is independent of the dispersion of income across MSAs. Rather, the ratio of average rental 
price per unit to aggregate per-capita income is equal to the expenditure share on housing divided by the average quantity of housing consumed per-household:

$$
\frac{\left(\frac{\sum_{i} r_{i} H_{i}}{\sum_{i} H_{i}}\right)}{\left(\frac{\sum_{i} n_{i} w_{i}}{\sum_{i} n_{i}}\right)}=\alpha\left(\frac{\sum_{i} H_{i}}{\mu}\right)^{-1} .
$$

Thus, while the model predicts that rental prices disproportionately reflect income differentials in the cross-section of MSAs at any given time, it also predicts that prices and per-capita incomes increase at the same rate over time in the aggregate, assuming per-capita housing in the aggregate is fixed.

\section{Model Fit}

After taking logs of equation (13), and recognizing that equation (13) holds for any $j$, the following expression links rental prices and wages in MSA $i$ to the average across all MSAs:

$$
\log \left(r_{i}\right)-\frac{1}{N} \sum_{j=1}^{N} \log \left(r_{j}\right)=\frac{1}{\alpha}\left[\log \left(w_{i}\right)-\frac{1}{N} \sum_{j=1}^{N} \log \left(w_{j}\right)\right] .
$$

Given this, we define $\bar{r}$ and $\bar{w}$ such that $\bar{r}=\exp \left\{\frac{1}{N} \sum_{j=1}^{N} \log \left(r_{j}\right)\right\}$ and $\bar{w}=\exp \left\{\frac{1}{N} \sum_{j=1}^{N} \log \left(w_{j}\right)\right\}$ and construct a predicted rental value in each MSA, $\widehat{r}_{i}$, as

$$
\widehat{r}_{i}=\bar{r}\left(\frac{w_{i}}{\bar{w}}\right)^{\frac{1}{\alpha}}
$$

We test the model by setting $\alpha=0.24$ and comparing the predicted value to the observed value $r_{i}$ for the year $2000 .^{12}$

In order to operationalize equation (18), we need to compute a standardized measure of income, $w_{i}$, appropriate for each MSA. To do this, we turn to micro data from the 2000 DCH. On an MSAby-MSA basis, we regress the log of reported wage and salary income for any person that worked at least 40 weeks in the previous year on a constant and a set of human capital variables. These variables include gender, age variables in 5-year bins, and categorical variables for educational attainment (nothing or missing, less than high school degree, high school degree, some college, college degree or more). These log wage regressions capture about 30 percent of the variation in $\log$ wages within each MSA. ${ }^{13}$

\footnotetext{
${ }^{12}$ Qualitatively, the results for 1980 and 1990 are identical to those that we document for 2000.

${ }^{13}$ For our rent and wage regressions, coefficients and $R^{2}$ values for each MSA are available on request.
} 
By regressing wages on age and education variables, we control for the variation in withinMSA wages that is attributable to differences in human capital. We use wage and salary income, rather than a broader measure that includes transfer or capital income, to focus on income-earning potential that is location specific. We consider only income of persons working 40 weeks or more the previous year to abstract from differences in average wages across MSAs that are attributable to differences in the number of part-time workers.

To compute a standardized wage that holds age and human capital constant across locations, we multiply the estimated regression coefficients in each MSA by the the fraction of workers for the entire U.S. that are appropriate for each dummy variable in the regression. Once we have computed this standardized wage for a representative full-time worker in each MSA, we multiply by 1.53 to compute average household income in that MSA; this is the average number of full time workers in each household, for all households that include at least one full time worker.

Our procedure to estimate constant quality rental prices $r_{i}$ consistently across MSAs is conceptually similar. On an MSA-by-MSA basis, we regress the level of gross rents paid by renting households on available characteristics of the housing unit and the method and time of commute (home to work) of the highest income earner in the household. For housing-unit characteristics, we include categorical variables describing the number of rooms, the number of bedrooms, the year the unit was built, and the total number of units in the building in which the unit is located, and from these categorical variables, we generate a full set of dummy variables. For the method of commute of the household's highest income earner, we subdivide responses into three dummy variables corresponding to the use of private automobiles, public transportation, or walking/biking. For commute time of the highest income earner, we use the recorded response. ${ }^{14}$ These rent regressions capture about 25 percent of the variation in reported rental expenditures within each MSA.

Using the regression coefficients for each MSA, we predict the level of rent, by MSA, for a fourroom, two-bedroom unit located in a 5-9 family building, where the primary wage earner commutes 15 minutes by private auto. The building itself is assumed to have been built between 1960 and 1969. These are the median readings of these variables for our sample of renting households in the U.S.

Our estimates of standardized wages and rental prices, $w_{i}$ and $r_{i}$, for the year 2000 are listed in the first two columns of Table 2, which is sorted in descending order by standardized wages. Rental prices are high in high-wage places: The correlation of rental prices and wages is 0.81 . The

\footnotetext{
${ }^{14}$ We create a separate dummy variable for households with a recorded commute of zero minutes.
} 
third and fourth columns of the table show predicted rental prices based on equation (18), $\widehat{r}_{i}$, and the difference of the observed and predicted rental rate, denoted $e_{i}$. These two columns show that the model predicts too much dispersion in rental prices given the observed wage dispersion. The correlation of $e_{i}$ and $w_{i}$ is -0.92 . Rental prices are not high enough in high-wage places and rental prices are too high in low wage places.

We perform two sensitivity analysis to ensure that this finding of a negative correlation is a robust feature of data. First, we eliminate home-owners from our regressions and computations of MSA-average wages, so that MSA-specific calculations of $r_{i}$ and $w_{i}$ are from exactly the same samples of renting households. Second, and separately, we include only households where (a) the primary respondent of the household has moved to a different metropolitan area within the past 5 years and (b) the previous metropolitan area of residence is directly identifiable. Although our estimates of $w_{i}$ change in the first analysis, and $w_{i}$ and $r_{i}$ both change in the second analysis, in both analyses we find that the correlation of $e_{i}$ and $w_{i}$ is approximately -0.9 .

One question that arises is whether a small change in $\alpha$ more closely aligns predicted rental rates with observed rental rates. It is possible to show that potentially reasonable changes to $\alpha$ are not sufficient to drive the correlation of $e_{i}$ and $w_{i}$ to zero. For example, at $\alpha=0.35$, the correlation of $e_{i}$ and $w_{i}$ is -0.65 . When $\alpha=0.52$, the correlation falls to zero.

Thus, our finding that $w_{i}$ and $e_{i}$ are negatively correlated seems quite robust, since in economic terms, expenditure shares of fifty percent are far from the 24 percent we estimate. However, it has recently been argued (Albouy 2007) that some fraction of consumption is produced locally. If the prices of locally-produced consumption goods are correlated with wages, then wages after accounting for variation in consumption prices are likely less dispersed than nominal wages. If wages are less dispersed, predicted rental prices will also be less dispersed holding $\alpha$ constant.

Data on local consumption prices in 2000 by MSA is available from the 2000 ACCRA (American Chamber of Commerce Researchers Association) Cost of Living Index, as published by the Council for Community and Economic Research. ACCRA participants collect price-level data on 59 nonhousing items, grouped broadly into 5 non-housing categories - Grocery (26 questions), Utilities (6), Transportation (2), Health care (5), and Miscellaneous (20). The questions range from the price of a box of Corn Flakes (Grocery) to the average price per game of bowling on Saturday evening between 6 and $10 \mathrm{pm}$ (Miscellaneous). ${ }^{15}$ For each of these 5 categories, ACCRA constructs a local price level based on the sample of prices of the individual items, and sets the average price

\footnotetext{
${ }^{15}$ The complete list of questions is available at http://www.coli.org/SurveyForms/PricingSurveyForm.pdf.
} 
level across sampled MSAs for each of the 6 categories to 100. ACCRA also reports expenditure shares for each of the categories in 2000: Grocery (0.16), Utilities (0.08), Transportation (0.10), Health Care (0.05), and Miscellaneous (0.33).

To explicitly incorporate local prices in our model, and in a manner that is consistent with the construction of the ACCRA data, we assume that households have Cobb-Douglas preferences over a bundle of $S$ consumption goods and housing. That is, utility in city $i$ is assumed to be of the form

$$
\left(\prod_{s=1}^{S} c_{i, s}^{\beta_{s}}\right) h_{i}^{\alpha},
$$

and households are subject to the budget constraint

$$
\sum_{s=1}^{S} p_{i, s} c_{i, s}+r_{i} h_{i} \leq w_{i},
$$

where we assume that $\sum_{s=1}^{S} \beta_{s}+\alpha=1$. With Cobb-Douglas preferences, households optimally choose constant expenditure shares on the bundle of all consumption items and housing, $p_{i, s} c_{i, s}=$ $\beta_{s} w_{i}$ and $r_{i} h_{i}=\alpha w_{i}$.

Given the assumptions, in equilibrium the following relationship holds between rental prices, wages, and consumption prices in any two MSAs $i$ and $j$ :

$$
\left(\frac{r_{i}}{r_{j}}\right)=\left(\frac{\widetilde{w_{i}}}{{\widetilde{w_{j}}}^{\frac{1}{\alpha}}}\right)^{\frac{1}{2}}
$$

where

$$
\widetilde{w_{k}}=\frac{w_{k}}{\prod_{s=1}^{S} p_{k, s}^{\beta_{s}}} .
$$

After adjusting nominal wages for consumption prices, as in equation (22), we predict rental prices using an equation like (18), with $w_{k}$ replaced by $\widetilde{w_{k}}$ and with $\bar{r}_{i}$ and $\bar{w}_{i}$ appropriately redefined.

We compute $\prod_{s=1}^{S} p_{i, s}^{\beta_{s}}$ for 48 of our 50 MSAs, the exceptions being Buffalo, NY and Bakersfield, CA. ${ }^{16}$ We match the ACCRA metropolitan division codes to the relevant MSAs, but for about 10 of the larger MSAs, the ACCRA survey only covers a subset of metropolitan divisions within the MSA. We suspect this distinction is probably not of quantitative importance, except perhaps for the New York, NY MSA, in which we find the level of consumption prices is about 13 percent higher than the next-most pricey MSA, San Francisco, CA. ${ }^{17}$ We assume households consume a basket of

\footnotetext{
${ }^{16}$ ACCRA also does not provide consumption price data for San Jose, CA, but in this case we set the consumption prices equal to those in San Francisco, CA.

${ }^{17}$ In the New York MSA, the only included metropolitan division (of four in total) is the "New York-White PlainsWayne" division.
} 
$S=5$ consumption items - groceries, utilities, transportation, health care, and miscellaneous - and proportionately rescale each of the 5 ACCRA expenditure shares so that the sum $\sum_{s=1}^{5} \beta_{s}=0.76$, which yields a 24 percent expenditure share on housing.

For the MSAs in our sample, Table 3 shows nominal wages, $w_{i}$, our estimate of consumption prices, $p_{i}=\prod_{s=1}^{S} p_{i, s}^{\beta_{s}}$ (after a simple rescaling such that the average of $p_{i}$ across MSAs is equal to $1.0)$, wages after adjusting for prices as in equation $(22), \widetilde{w_{i}}$, actual rental prices, $r_{i}$, and predicted rental prices after wages have been adjusted for consumption prices, $\widetilde{r}_{i}$. Like Table 2 , Table 3 is sorted in descending order of nominal wages. The correlation of nominal wages and consumption price levels $\left(p_{i}\right)$ is high, 0.54. Even so, Table 3 shows that, on average, rental prices are still too low in places that offer relatively high wages after accounting for consumption prices: At $\alpha=0.24$, the correlation of the gap between actual and predicted rental prices, $e_{i}$, and adjusted income, $\widetilde{w_{i}}$, shown in Table 3 is -0.74 . Further, the value of $\alpha$ required to set this correlation to zero is 0.76 .

A final and related point is that we are aware we can more accurately predict rental prices given the distribution of wages if we are willing to redefine household utility. Ignoring variation in local consumption prices, suppose utility in city $i$ is defined as $z_{i} c_{i}^{1-\alpha} h_{i}^{\alpha}$. In equilibrium, indifference across MSAs requires

$$
\frac{r_{i}}{r_{j}}=\left(\frac{z_{i} w_{i}}{z_{j} w_{j}}\right)^{\frac{1}{\alpha}} .
$$

Whatever $z_{i}$ is, assuming $\alpha=0.24$, it must be negatively correlated with wages. It could perhaps be a "quality of life" variable, as in Kahn (1995) or Rappaport (2006), or perhaps could be related to congestion externalities linked to density. Rather than tell a story about $z_{i}$, we note the following: Without $z_{i}$, a simple model of location choice that reproduces the observation that housing expenditure shares are constant across locations predicts that rental prices of the highest-wage MSAs are higher that currently observed.

\section{Conclusions}

We use aggregate data from the NIPA and micro data from the 1980, 1990, and 2000 DCH to document that the expenditure share on housing is remarkably constant across MSAs and over time. We engineer a simple model consistent with this observation and explore its predictions. The model predicts more dispersion in rental prices than is observed in the data. In other words, the model suggests that rental prices aren't high enough for high-wage MSAs and aren't low enough 
for low wage MSAs. This result holds true even once we adjust local wages for variation in the price of consumption goods.

A key distinguishing feature of our general spatial equilibrium model, relative to many papers in the urban economics literature, is our use of Cobb-Douglas preferences. This assumption yields a constant housing expenditure share in equilibrium, consistent with the evidence we uncover. The same assumption has been used to study the internal structure of cities (Lucas 2001 and Lucas and Rossi-Hansberg 2002) and to explain the distribution of population across MSAs (Eeckhout 2004). At the aggregate level, the assumption of Cobb-Douglas preferences is consistent with the popular view that the ratio of the average price of houses to income should be constant. This paper demonstrates that this insight from aggregate models is misleading when applied to MSA-level data.

\section{References}

[1] Albouy, D., 2007, "The Unequal Geographic Burden of Federal Taxation and Its Consequences: A Case for Tax Deductions?" Mimeo, University of Michigan

[2] Bureau of Economic Analysis, 1990, Personal Consumption Expenditures, available at: http://www.bea.gov/bea/ARTICLES/NATIONAL/NIPA/Methpap/methpap6.pdf.

[3] Campbell, S., Davis, M., Gallin, J. and R. Martin, 2007, "What Moves Housing Markets: A Variance Decomposition of the Rent-Price Ratio," Mimeo, University of Wisconsin-Madison.

[4] Case, K. and R. Shiller, 2004, "Is There a Bubble in the Housing Market? An Analysis," Brookings Papers on Economic Activity, 299-362.

[5] Davis, M. A. and J. Heathcote, 2005, "Housing and the Business Cycle," International Economic Review 46, 751-784.

[6] Davis, M. A. and J. Heathcote, 2007, "The Price and Quantity of Residential Land in the United States," Journal of Monetary Economics 54, 2595-2620.

[7] Eeckhout, J., 2004, "Gilbrat's Law for All Cities," American Economic Review 95, 1429-1451.

[8] Fernandez-Villaverde, J., and D. Krueger, 2005, "Borrowing Constraints, Durables, and the Business Cycle," Mimeo, University of Pennsylvania.

[9] Fisher, J., 1997, "Relative Prices, Complementarities, and Comovement among Components of Aggregate Expenditures," Journal of Monetary Economics 39, 449-474.

[10] Fisher, J., 2007, "Why Does Household Investment Lead Business Investment over the Business Cycle?," Journal of Political Economy 115, 141-168.

[11] Flavin, M. and S. Nakagawa, 2007, "A Model of Housing in the Presence of Adjustment Costs: A Structural Interpretation of Habit Persistence," American Economic Review, forthcoming.

[12] Gallin, J., 2006, "The Long-Run Relationship between House Prices and Income: Evidence from Local Housing Markets," Real Estate Economics 34, 417-438. 
[13] Gervais, M., 2002, "Housing taxation and capital accumulation," Journal of Monetary Economics 49, 1461-1489.

[14] Gomme, P., Kydland, F., and P. Rupert, 2001, "Home Production Meets Time to Build," Journal of Political Economy 109, 1115-1131.

[15] Greenwood, J., Rogerson, R. and R. Wright, 1995, "Household Production in Real Business Cycle Theory," In Frontiers of Business Cycle Research, edited by Thomas F. Cooley. Princeton University Press.

[16] Gyourko, J., Mayer, C. and T. Sinai, 2006, "Superstar Cities," Mimeo, University of Pennsylvania.

[17] Iacoviello, M., 2005, "House Prices, Borrowing Constraints and Monetary Policy in the Business Cycle," American Economic Review 95, 739-764.

[18] Kahn, M., 1995, “A Revealed Preference Approach to Ranking City Quality of Life," Journal of Urban Economics 38, 221-235.

[19] Kiyotaki, N., Michaelides, A. and K. Nikolov, 2007, "Winners and Losers in Housing Markets," Mimeo, London School of Economics.

[20] Li, W. and R. Yao, 2006, "The Life Cycle Effects of House Price Changes," Journal of Money, Credit, and Banking, forthcoming.

[21] Lucas, R. E., 2001, "Externalities and Cities," Review of Economic Dynamics 4, 245-274.

[22] Lucas, R. E. and E. Rossi-Hansberg, 2002, "On the Internal Structure of Cities," Econometrica $70,1445-1476$.

[23] Lustig, H. and S. Van Nieuwerburgh, 2006, "Exploring the Link between Housing and the Value Premium," Mimeo, UCLA.

[24] Malpezzi, S., 1999, "A Simple Error Correction Model of Housing Prices," Journal of Housing Economics 8, 27-62.

[25] Ortalo-Magné, F. and A. Prat, 2007, "Spatial Asset Pricing," Mimeo, University of Wisconsin.

[26] Piazzesi, M., Schneider, M. and S. Tuzel, 2007, "Housing, Consumption, and Asset Pricing," Journal of Financial Economics, 83, 531-569.

[27] Rappaport, J., 2006, "Consumption Amenities and City Crowdedness," Federal Reserve Bank of Kansas City Working Paper RWP 06-10.

[28] Van Nieuwerburgh, S. and P. Weill, 2007, "Why Has House Price Dispersion Gone Up?", Mimeo, New York University.

[29] Verbrugge, R., 2006, "The Puzzling Divergence of Rents and User Costs, 1980-2004," OECDIMF Workshop in Real Estate Price Indexes Paper 22. 
Figure 1: Aggregate Expenditure Share on Housing from the NIPA, 1929-2006

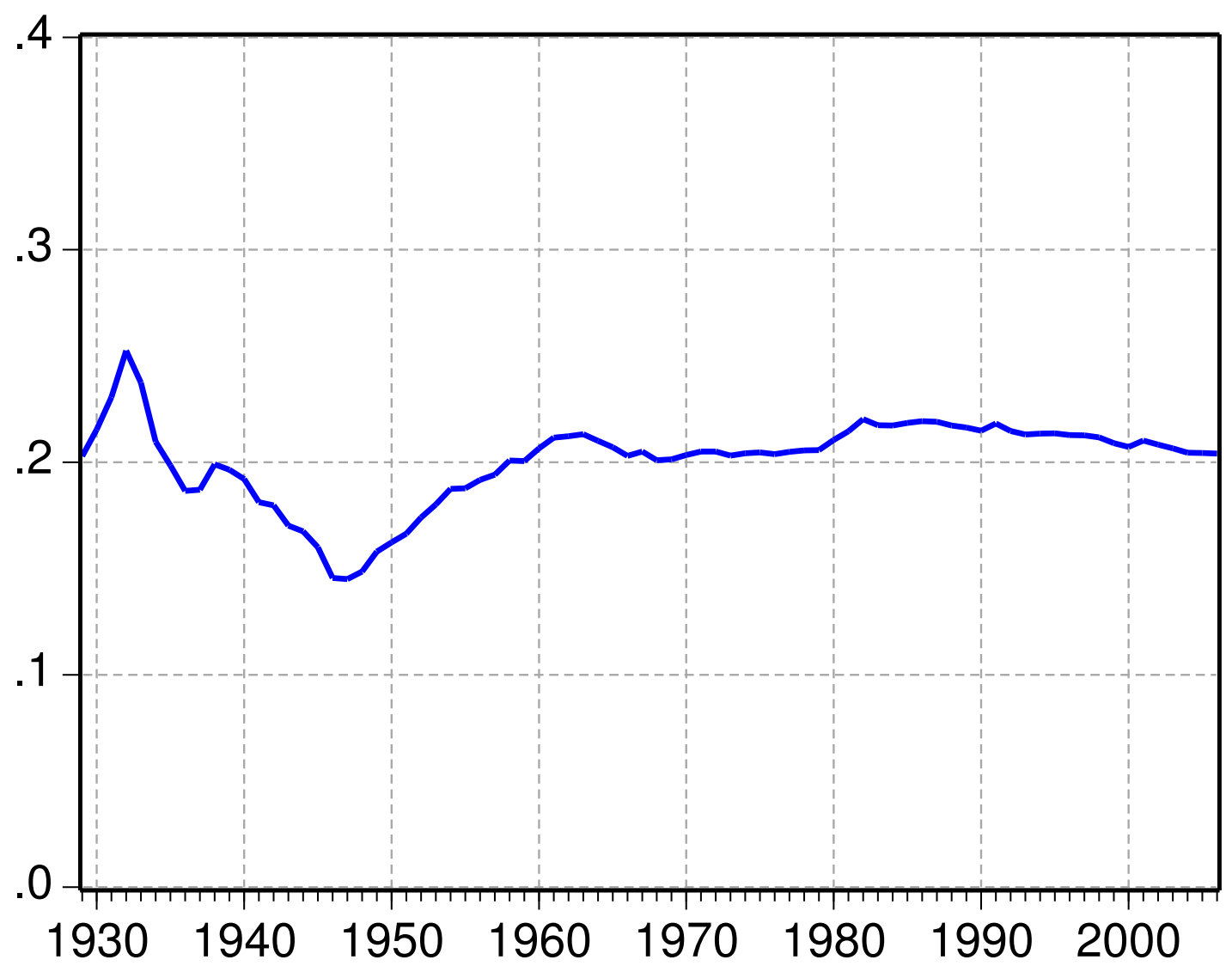


Figure 2: 1980, 1990, 2000 DCH: Coefficients of Regression Output of Age on the Deviations of Log Inverse of Expenditure Share

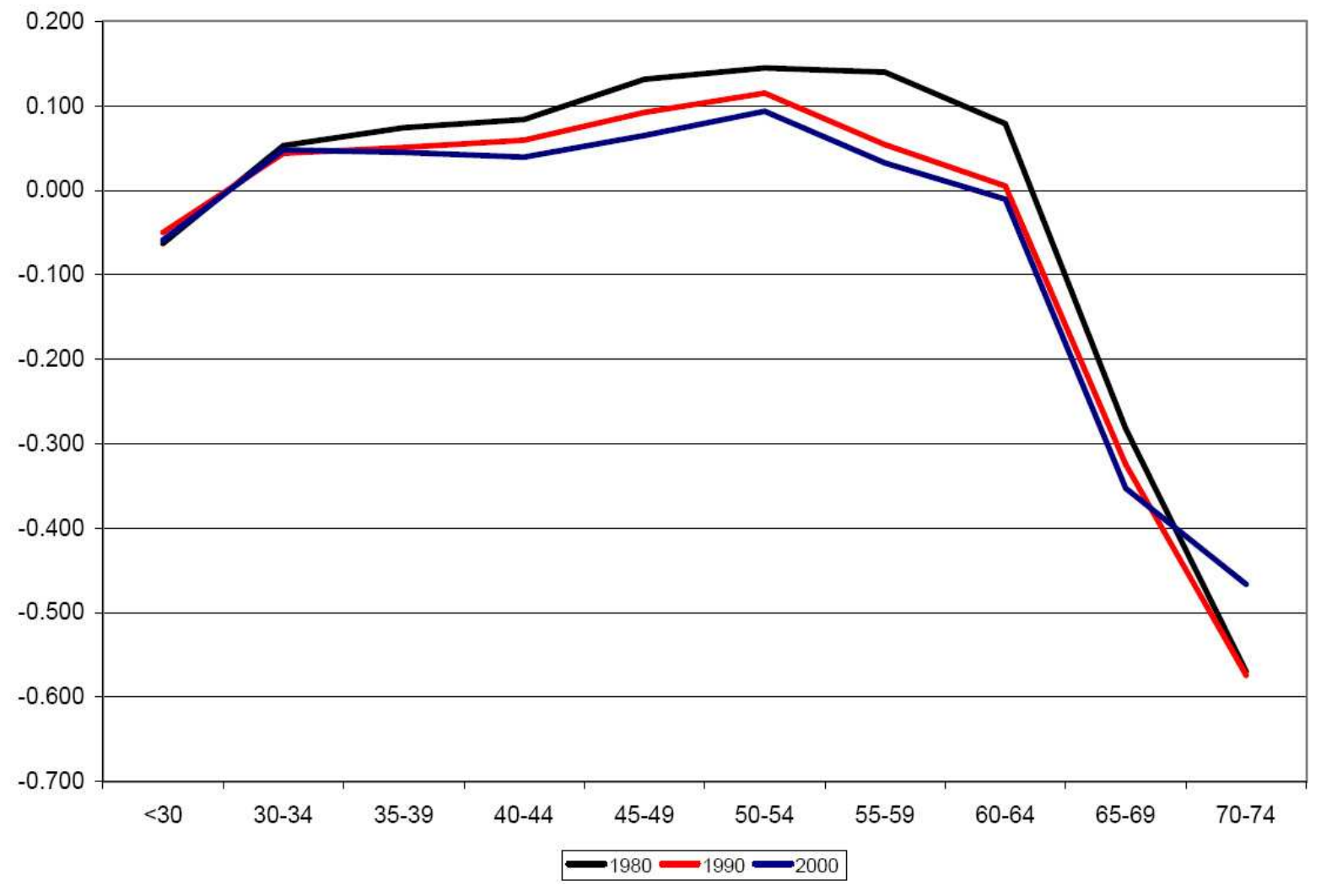


Table 1

Median Ratio of Rental Expenditures to Wage and Salary Income (1980, 1990, and 2000), Average Income around Median Ratio (2000), Growth in Real Rental Prices (1980-2000)

\begin{tabular}{|c|c|c|c|c|c|}
\hline \multirow[b]{2}{*}{ MSA } & \multicolumn{3}{|c|}{ Median Ratio } & \multirow{2}{*}{$\begin{array}{l}\text { HH Inc. at Median } \\
\text { Rent-Income }(2000)\end{array}$} & \multirow{2}{*}{$\begin{array}{c}\text { Real Rent Growth, } \\
1980-2000\end{array}$} \\
\hline & 1980 & 1990 & 2000 & & \\
\hline Albany-Schenectady-Troy & 0.21 & 0.23 & 0.23 & $\$ 32,035$ & $15.9 \%$ \\
\hline Atlanta-Sandy Springs-Marietta & 0.24 & 0.25 & 0.25 & $\$ 37,304$ & $24.6 \%$ \\
\hline Austin-Round Rock & 0.27 & 0.25 & 0.25 & $\$ 35,948$ & $42.2 \%$ \\
\hline Bakersfield & 0.28 & 0.25 & 0.25 & $\$ 29,860$ & $2.7 \%$ \\
\hline Baltimore-Towson & 0.23 & 0.23 & 0.23 & $\$ 35,076$ & $34.8 \%$ \\
\hline Boston-Cambridge-Quincy & 0.24 & 0.26 & 0.24 & $\$ 43,284$ & $53.4 \%$ \\
\hline Buffalo-Niagara Falls & 0.20 & 0.22 & 0.23 & $\$ 32,368$ & $21.2 \%$ \\
\hline Charlotte-Gastonia-Concord & 0.23 & 0.24 & 0.24 & $\$ 39,772$ & $27.5 \%$ \\
\hline Chicago-Naperville-Joliet & 0.21 & 0.23 & 0.23 & $\$ 38,677$ & $33.5 \%$ \\
\hline Cincinnati-Middletown & 0.21 & 0.22 & 0.20 & $\$ 35,685$ & $5.6 \%$ \\
\hline Cleveland-Elyria-Mentor & 0.21 & 0.22 & 0.23 & $\$ 34,058$ & $4.8 \%$ \\
\hline Columbus & 0.22 & 0.23 & 0.23 & $\$ 31,981$ & $37.8 \%$ \\
\hline Dallas-Fort Worth-Arlington & 0.24 & 0.24 & 0.24 & $\$ 36,540$ & $32.7 \%$ \\
\hline Denver-Aurora & 0.25 & 0.24 & 0.26 & $\$ 36,804$ & $19.2 \%$ \\
\hline Detroit-Warren-Livonia & 0.21 & 0.22 & 0.22 & $\$ 36,719$ & $6.9 \%$ \\
\hline Fresno & 0.25 & 0.27 & 0.26 & $\$ 28,924$ & $13.3 \%$ \\
\hline Grand Rapids-Wyoming & 0.19 & 0.24 & 0.21 & $\$ 28,742$ & $16.8 \%$ \\
\hline Greensboro-High Point & 0.24 & 0.23 & 0.22 & $\$ 32,231$ & $23.8 \%$ \\
\hline Houston-Sugar Land-Baytown & 0.23 & 0.22 & 0.23 & $\$ 35,205$ & $7.4 \%$ \\
\hline Indianapolis-Carmel & 0.21 & 0.23 & 0.23 & $\$ 33,158$ & $8.4 \%$ \\
\hline Jacksonville & 0.27 & 0.24 & 0.25 & $\$ 31,737$ & $4.2 \%$ \\
\hline Kansas City & 0.21 & 0.22 & 0.22 & $\$ 36,521$ & $21.7 \%$ \\
\hline Las Vegas-Paradise & 0.29 & 0.27 & 0.27 & $\$ 34,275$ & $19.6 \%$ \\
\hline Los Angeles-Long Beach-Santa Ana & 0.25 & 0.29 & 0.27 & $\$ 38,494$ & $36.9 \%$ \\
\hline Louisville-Jefferson County & 0.22 & 0.23 & 0.21 & $\$ 33,518$ & $4.6 \%$ \\
\hline Miami-Fort Lauderdale-Pompano Beach & 0.27 & 0.29 & 0.29 & $\$ 29,604$ & $24.7 \%$ \\
\hline Milwaukee-Waukesha-West Allis & 0.20 & 0.23 & 0.22 & $\$ 33,662$ & $12.5 \%$ \\
\hline Minneapolis-St. Paul-Bloomington & 0.24 & 0.25 & 0.23 & $\$ 37,011$ & $19.1 \%$ \\
\hline Nashville-Davidson-Murfreesboro-Franklin & 0.23 & 0.24 & 0.24 & $\$ 31,590$ & $23.8 \%$ \\
\hline New Orleans-Metairie-Kenner & 0.24 & 0.25 & 0.24 & $\$ 28,713$ & $24.4 \%$ \\
\hline New York-Northern New Jersey-Long Island & 0.22 & 0.24 & 0.24 & $\$ 45,805$ & $38.6 \%$ \\
\hline Orlando-Kissimmee & 0.26 & 0.27 & 0.27 & $\$ 33,704$ & $40.9 \%$ \\
\hline Philadelphia-Camden-Wilmington & 0.22 & 0.24 & 0.23 & $\$ 38,491$ & $32.9 \%$ \\
\hline Phoenix-Mesa-Scottsdale & 0.28 & 0.26 & 0.26 & $\$ 34,026$ & $9.1 \%$ \\
\hline Pittsburgh & 0.21 & 0.21 & 0.22 & $\$ 31,872$ & $10.5 \%$ \\
\hline Portland-Vancouver-Beaverton & 0.27 & 0.24 & 0.25 & $\$ 33,893$ & $19.3 \%$ \\
\hline Riverside-San Bernardino-Ontario & 0.26 & 0.28 & 0.27 & $\$ 35,622$ & $17.8 \%$ \\
\hline Sacramento-Arden-Arcade-Roseville & 0.25 & 0.28 & 0.26 & $\$ 35,352$ & $39.0 \%$ \\
\hline St. Louis & 0.22 & 0.23 & 0.22 & $\$ 33,966$ & $4.2 \%$ \\
\hline Salt Lake City & 0.24 & 0.23 & 0.27 & $\$ 32,980$ & $23.2 \%$ \\
\hline San Antonio & 0.22 & 0.24 & 0.24 & $\$ 30,686$ & $14.1 \%$ \\
\hline San Diego-Carlsbad-San Marcos & 0.29 & 0.30 & 0.28 & $\$ 36,050$ & $38.5 \%$ \\
\hline San Francisco-Oakland-Fremont & 0.26 & 0.28 & 0.25 & $\$ 52,422$ & $70.8 \%$ \\
\hline San Jose-Sunnyvale-Santa Clara & 0.24 & 0.26 & 0.25 & $\$ 58,680$ & $110.4 \%$ \\
\hline Seattle-Tacoma-Bellevue & 0.25 & 0.25 & 0.26 & $\$ 39,303$ & $33.8 \%$ \\
\hline Syracuse & 0.24 & 0.24 & 0.24 & $\$ 28,248$ & $16.6 \%$ \\
\hline Tampa-St. Petersburg-Clearwater & 0.26 & 0.25 & 0.25 & $\$ 32,972$ & $22.9 \%$ \\
\hline Tucson & 0.26 & 0.29 & 0.26 & $\$ 30,111$ & $-2.6 \%$ \\
\hline Tulsa & 0.23 & 0.22 & 0.23 & $\$ 29,600$ & $1.2 \%$ \\
\hline Washington-Arlington-Alexandria & 0.23 & 0.26 & 0.24 & $\$ 47,994$ & $46.4 \%$ \\
\hline Average & 0.24 & 0.25 & 0.24 & $\$ 35,425$ & $24.2 \%$ \\
\hline Standard Deviation & 0.02 & 0.02 & 0.02 & $\$ 5,867$ & $19.5 \%$ \\
\hline
\end{tabular}


Table 2

Wages $\left(w_{i}\right)$, observed rents $\left(r_{i}\right)$, predicted rents $\left(\hat{r}_{i}\right)$, and error $\left(e_{i}=r_{i}-\hat{r}_{i}\right), 2000$

\begin{tabular}{|c|c|c|c|c|}
\hline$\overline{\mathrm{MSA}}$ & $\overline{w_{i}}$ & $\overline{r_{i}}$ & $\hat{r}_{i}$ & $e_{i}$ \\
\hline San Jose-Sunnyvale-Santa Clara & $\$ 73,095$ & $\$ 1,266$ & $\$ 2,005$ & $-\$ 739$ \\
\hline San Francisco-Oakland-Fremont & $\$ 65,618$ & $\$ 1,030$ & $\$ 1,279$ & $-\$ 249$ \\
\hline New York-Northern New Jersey-Long Island & $\$ 65,272$ & $\$ 797$ & $\$ 1,251$ & $-\$ 454$ \\
\hline Washington-Arlington-Alexandria & $\$ 63,868$ & $\$ 825$ & $\$ 1,143$ & $-\$ 318$ \\
\hline Boston-Cambridge-Quincy & $\$ 62,209$ & $\$ 887$ & $\$ 1,024$ & $-\$ 137$ \\
\hline Chicago-Naperville-Joliet & $\$ 61,805$ & $\$ 727$ & $\$ 997$ & $-\$ 269$ \\
\hline Detroit-Warren-Livonia & $\$ 61,750$ & $\$ 680$ & $\$ 993$ & $-\$ 313$ \\
\hline Philadelphia-Camden-Wilmington & $\$ 59,862$ & $\$ 748$ & $\$ 873$ & $-\$ 125$ \\
\hline Dallas-Fort Worth-Arlington & $\$ 59,476$ & $\$ 612$ & $\$ 849$ & $-\$ 237$ \\
\hline Los Angeles-Long Beach-Santa Ana & $\$ 58,933$ & $\$ 867$ & $\$ 818$ & $\$ 50$ \\
\hline Atlanta-Sandy Springs-Marietta & $\$ 58,703$ & $\$ 655$ & $\$ 804$ & $-\$ 149$ \\
\hline Houston-Sugar Land-Baytown & $\$ 58,678$ & $\$ 606$ & $\$ 803$ & $-\$ 197$ \\
\hline Seattle-Tacoma-Bellevue & $\$ 58,612$ & $\$ 785$ & $\$ 799$ & $-\$ 14$ \\
\hline Baltimore-Towson & $\$ 58,351$ & $\$ 694$ & $\$ 784$ & $-\$ 90$ \\
\hline Charlotte-Gastonia-Concord & $\$ 57,836$ & $\$ 625$ & $\$ 756$ & $-\$ 131$ \\
\hline Denver-Aurora & $\$ 57,676$ & $\$ 633$ & $\$ 747$ & $-\$ 115$ \\
\hline Minneapolis-St. Paul-Bloomington & $\$ 57,272$ & $\$ 655$ & $\$ 726$ & $-\$ 71$ \\
\hline Sacramento-Arden-Arcade-Roseville & $\$ 56,525$ & $\$ 613$ & $\$ 687$ & $-\$ 74$ \\
\hline Austin-Round Rock & $\$ 56,389$ & $\$ 672$ & $\$ 680$ & $-\$ 9$ \\
\hline Cincinnati-Middletown & $\$ 55,831$ & $\$ 519$ & $\$ 653$ & $-\$ 134$ \\
\hline Las Vegas-Paradise & $\$ 55,831$ & $\$ 636$ & $\$ 653$ & $-\$ 17$ \\
\hline Phoenix-Mesa-Scottsdale & $\$ 55,813$ & $\$ 622$ & $\$ 652$ & $-\$ 30$ \\
\hline Indianapolis-Carmel & $\$ 55,437$ & $\$ 562$ & $\$ 634$ & $-\$ 72$ \\
\hline San Diego-Carlsbad-San Marcos & $\$ 55,296$ & $\$ 754$ & $\$ 627$ & $\$ 127$ \\
\hline Kansas City & $\$ 55,152$ & $\$ 633$ & $\$ 620$ & $\$ 12$ \\
\hline Cleveland-Elyria-Mentor & $\$ 55,128$ & $\$ 544$ & $\$ 619$ & $-\$ 75$ \\
\hline Riverside-San Bernardino-Ontario & $\$ 55,034$ & $\$ 593$ & $\$ 615$ & $-\$ 22$ \\
\hline Portland-Vancouver-Beaverton & $\$ 54,878$ & $\$ 617$ & $\$ 607$ & $\$ 10$ \\
\hline Milwaukee-Waukesha-West Allis & $\$ 54,463$ & $\$ 625$ & $\$ 589$ & $\$ 37$ \\
\hline Louisville-Jefferson County & $\$ 53,942$ & $\$ 447$ & $\$ 565$ & $-\$ 118$ \\
\hline Columbus & $\$ 53,773$ & $\$ 602$ & $\$ 558$ & $\$ 44$ \\
\hline St. Louis & $\$ 53,678$ & $\$ 548$ & $\$ 554$ & $-\$ 5$ \\
\hline Grand Rapids-Wyoming & $\$ 53,477$ & $\$ 504$ & $\$ 545$ & $-\$ 42$ \\
\hline Jacksonville & $\$ 53,000$ & $\$ 561$ & $\$ 525$ & $\$ 36$ \\
\hline Nashville-Davidson-Murfreesboro-Franklin & $\$ 52,972$ & $\$ 538$ & $\$ 524$ & $\$ 14$ \\
\hline Greensboro-High Point & $\$ 52,696$ & $\$ 509$ & $\$ 513$ & $-\$ 4$ \\
\hline Tampa-St. Petersburg-Clearwater & $\$ 52,505$ & $\$ 622$ & $\$ 505$ & $\$ 117$ \\
\hline Bakersfield & $\$ 52,436$ & $\$ 459$ & $\$ 502$ & $-\$ 43$ \\
\hline Salt Lake City & $\$ 52,086$ & $\$ 584$ & $\$ 489$ & $\$ 96$ \\
\hline Albany-Schenectady-Troy & $\$ 51,569$ & $\$ 642$ & $\$ 469$ & $\$ 174$ \\
\hline Tulsa & $\$ 51,329$ & $\$ 502$ & $\$ 460$ & $\$ 42$ \\
\hline Orlando-Kissimmee & $\$ 50,795$ & $\$ 634$ & $\$ 440$ & $\$ 194$ \\
\hline Miami-Fort Lauderdale-Pompano Beach & $\$ 50,172$ & $\$ 722$ & $\$ 418$ & $\$ 304$ \\
\hline Syracuse & $\$ 49,600$ & $\$ 557$ & $\$ 399$ & $\$ 158$ \\
\hline San Antonio & $\$ 49,505$ & $\$ 560$ & $\$ 395$ & $\$ 165$ \\
\hline Fresno & $\$ 48,902$ & $\$ 509$ & $\$ 376$ & $\$ 134$ \\
\hline New Orleans-Metairie-Kenner & $\$ 48,863$ & $\$ 569$ & $\$ 374$ & $\$ 194$ \\
\hline Buffalo-Niagara Falls & $\$ 48,657$ & $\$ 593$ & $\$ 368$ & $\$ 225$ \\
\hline Pittsburgh & $\$ 48,496$ & $\$ 538$ & $\$ 363$ & $\$ 175$ \\
\hline Tucson & $\$ 46,576$ & $\$ 512$ & $\$ 307$ & $\$ 206$ \\
\hline Average & $\$ 55,596$ & $\$ 644$ & $\$ 679$ & $-\$ 35$ \\
\hline Standard Deviation & $\$ 5,118$ & $\$ 145$ & $\$ 296$ & $\$ 187$ \\
\hline
\end{tabular}


Table 3

Wages $\left(w_{i}\right)$, consumption prices $\left(p_{i}=\prod_{s=1}^{S} p_{i, s}^{\beta_{s}}\right)$, adjusted wages $\left(\tilde{w}_{i}\right)$, observed rents $\left(r_{i}\right)$, predicted rents based on adjusted wages $\left(\tilde{r}_{i}\right)$, and error $\left(e_{i}=r_{i}-\tilde{r}_{i}\right), 2000$

\begin{tabular}{|c|c|c|c|c|c|c|}
\hline$\overline{\mathrm{MSA}}$ & $\overline{w_{i}}$ & $p_{i}$ & $\tilde{w}_{i}$ & $r_{i}$ & $\overline{\tilde{r}_{i}}$ & $e_{i}$ \\
\hline San Jose-Sunnyvale-Santa Clara & $\$ 73,095$ & 1.13 & $\$ 64,650$ & $\$ 1,266$ & $\$ 1,184$ & $\$ 82$ \\
\hline San Francisco-Oakland-Fremont & $\$ 65,618$ & 1.13 & $\$ 58,037$ & $\$ 1,030$ & $\$ 755$ & $\$ 275$ \\
\hline New York-Northern New Jersey-Long Island & $\$ 65,272$ & 1.26 & $\$ 51,954$ & $\$ 797$ & $\$ 476$ & $\$ 321$ \\
\hline Washington-Arlington-Alexandria & $\$ 63,868$ & 1.04 & $\$ 61,679$ & $\$ 825$ & $\$ 973$ & $-\$ 148$ \\
\hline Boston-Cambridge-Quincy & $\$ 62,209$ & 1.08 & $\$ 57,514$ & $\$ 887$ & $\$ 727$ & $\$ 160$ \\
\hline Chicago-Naperville-Joliet & $\$ 61,805$ & 1.02 & $\$ 60,576$ & $\$ 727$ & $\$ 903$ & $-\$ 175$ \\
\hline Detroit-Warren-Livonia & $\$ 61,750$ & 0.99 & $\$ 62,625$ & $\$ 680$ & $\$ 1,037$ & $-\$ 357$ \\
\hline Philadelphia-Camden-Wilmington & $\$ 59,862$ & 1.04 & $\$ 57,481$ & $\$ 748$ & $\$ 726$ & $\$ 22$ \\
\hline Dallas-Fort Worth-Arlington & $\$ 59,476$ & 0.98 & $\$ 60,838$ & $\$ 612$ & $\$ 919$ & $-\$ 307$ \\
\hline Los Angeles-Long Beach-Santa Ana & $\$ 58,933$ & 1.03 & $\$ 57,166$ & $\$ 867$ & $\$ 709$ & $\$ 158$ \\
\hline Atlanta-Sandy Springs-Marietta & $\$ 58,703$ & 0.97 & $\$ 60,640$ & $\$ 655$ & $\$ 907$ & $-\$ 252$ \\
\hline Houston-Sugar Land-Baytown & $\$ 58,678$ & 0.94 & $\$ 62,416$ & $\$ 606$ & $\$ 1,023$ & $-\$ 417$ \\
\hline Seattle-Tacoma-Bellevue & $\$ 58,612$ & 0.98 & $\$ 59,509$ & $\$ 785$ & $\$ 838$ & $-\$ 53$ \\
\hline Baltimore-Towson & $\$ 58,351$ & 0.95 & $\$ 61,279$ & $\$ 694$ & $\$ 947$ & $-\$ 253$ \\
\hline Charlotte-Gastonia-Concord & $\$ 57,836$ & 0.97 & $\$ 59,900$ & $\$ 625$ & $\$ 862$ & $-\$ 237$ \\
\hline Denver-Aurora & $\$ 57,676$ & 0.98 & $\$ 58,642$ & $\$ 633$ & $\$ 789$ & $-\$ 156$ \\
\hline Minneapolis-St. Paul-Bloomington & $\$ 57,272$ & 1.02 & $\$ 55,919$ & $\$ 655$ & $\$ 647$ & $\$ 8$ \\
\hline Sacramento-Arden-Arcade-Roseville & $\$ 56,525$ & 1.06 & $\$ 53,115$ & $\$ 613$ & $\$ 522$ & $\$ 91$ \\
\hline Austin-Round Rock & $\$ 56,389$ & 0.92 & $\$ 61,390$ & $\$ 672$ & $\$ 954$ & $-\$ 283$ \\
\hline Cincinnati-Middletown & $\$ 55,831$ & 0.96 & $\$ 58,197$ & $\$ 519$ & $\$ 764$ & $-\$ 245$ \\
\hline Las Vegas-Paradise & $\$ 55,831$ & 1.01 & $\$ 55,195$ & $\$ 636$ & $\$ 613$ & $\$ 23$ \\
\hline Phoenix-Mesa-Scottsdale & $\$ 55,813$ & 0.98 & $\$ 57,125$ & $\$ 622$ & $\$ 707$ & $-\$ 85$ \\
\hline Indianapolis-Carmel & $\$ 55,437$ & 0.95 & $\$ 58,430$ & $\$ 562$ & $\$ 777$ & $-\$ 215$ \\
\hline San Diego-Carlsbad-San Marcos & $\$ 55,296$ & 1.06 & $\$ 52,061$ & $\$ 754$ & $\$ 480$ & $\$ 273$ \\
\hline Kansas City & $\$ 55,152$ & 0.99 & $\$ 55,686$ & $\$ 633$ & $\$ 636$ & $-\$ 3$ \\
\hline Cleveland-Elyria-Mentor & $\$ 55,128$ & 1.03 & $\$ 53,721$ & $\$ 544$ & $\$ 547$ & $-\$ 3$ \\
\hline Riverside-San Bernardino-Ontario & $\$ 55,034$ & 1.07 & $\$ 51,660$ & $\$ 593$ & $\$ 465$ & $\$ 128$ \\
\hline Portland-Vancouver-Beaverton & $\$ 54,878$ & 0.99 & $\$ 55,247$ & $\$ 617$ & $\$ 615$ & $\$ 2$ \\
\hline Milwaukee-Waukesha-West Allis & $\$ 54,463$ & 0.96 & $\$ 56,938$ & $\$ 625$ & $\$ 697$ & $-\$ 72$ \\
\hline Louisville-Jefferson County & $\$ 53,942$ & 0.96 & $\$ 56,197$ & $\$ 447$ & $\$ 660$ & $-\$ 213$ \\
\hline Columbus & $\$ 53,773$ & 0.96 & $\$ 55,801$ & $\$ 602$ & $\$ 641$ & $-\$ 39$ \\
\hline St. Louis & $\$ 53,678$ & 0.96 & $\$ 55,669$ & $\$ 548$ & $\$ 635$ & $-\$ 86$ \\
\hline Grand Rapids-Wyoming & $\$ 53,477$ & 1.00 & $\$ 53,334$ & $\$ 504$ & $\$ 531$ & $-\$ 27$ \\
\hline Jacksonville & $\$ 53,000$ & 0.95 & $\$ 55,692$ & $\$ 561$ & $\$ 636$ & $-\$ 75$ \\
\hline Nashville-Davidson-Murfreesboro-Franklin & $\$ 52,972$ & 0.93 & $\$ 57,099$ & $\$ 538$ & $\$ 706$ & $-\$ 168$ \\
\hline Greensboro-High Point & $\$ 52,696$ & 0.94 & $\$ 55,998$ & $\$ 509$ & $\$ 651$ & $-\$ 142$ \\
\hline Tampa-St. Petersburg-Clearwater & $\$ 52,505$ & 0.97 & $\$ 54,109$ & $\$ 622$ & $\$ 564$ & $\$ 58$ \\
\hline Bakersfield & $\$ 52,436$ & & & & & \\
\hline Salt Lake City & $\$ 52,086$ & 0.98 & $\$ 53,279$ & $\$ 584$ & $\$ 529$ & $\$ 55$ \\
\hline Albany-Schenectady-Troy & $\$ 51,569$ & 1.00 & $\$ 51,524$ & $\$ 642$ & $\$ 460$ & $\$ 182$ \\
\hline Tulsa & $\$ 51,329$ & 0.94 & $\$ 54,800$ & $\$ 502$ & $\$ 595$ & $-\$ 93$ \\
\hline Orlando-Kissimmee & $\$ 50,795$ & 0.97 & $\$ 52,288$ & $\$ 634$ & $\$ 489$ & $\$ 145$ \\
\hline Miami-Fort Lauderdale-Pompano Beach & $\$ 50,172$ & 1.03 & $\$ 48,939$ & $\$ 722$ & $\$ 371$ & $\$ 351$ \\
\hline Syracuse & $\$ 49,600$ & 1.01 & $\$ 48,940$ & $\$ 557$ & $\$ 371$ & $\$ 186$ \\
\hline San Antonio & $\$ 49,505$ & 0.91 & $\$ 54,521$ & $\$ 560$ & $\$ 582$ & $-\$ 22$ \\
\hline Fresno & $\$ 48,902$ & 1.04 & $\$ 47,086$ & $\$ 509$ & $\$ 316$ & $\$ 193$ \\
\hline New Orleans-Metairie-Kenner & $\$ 48,863$ & 0.99 & $\$ 49,518$ & $\$ 569$ & $\$ 390$ & $\$ 179$ \\
\hline Buffalo-Niagara Falls & $\$ 48,657$ & & & & & \\
\hline Pittsburgh & $\$ 48,496$ & 1.01 & $\$ 47,874$ & $\$ 538$ & $\$ 339$ & $\$ 200$ \\
\hline Tucson & $\$ 46,576$ & 0.96 & $\$ 48,304$ & $\$ 512$ & $\$ 351$ & $\$ 161$ \\
\hline Average & $\$ 55,596$ & 1.00 & $\$ 55,845$ & $\$ 649$ & $\$ 667$ & $-\$ 18$ \\
\hline Standard Deviation & $\$ 5,118$ & 0.06 & $\$ 4,228$ & $\$ 146$ & $\$ 204$ & $\$ 187$ \\
\hline
\end{tabular}




\section{CESifo Working Paper Series}

for full list see www.cesifo-group.org/wp

(address: Poschingerstr. 5, 81679 Munich, Germany, office@cesifo.de)

2092 Henrik Jacobsen Kleven, Claus Thustrup Kreiner and Emmanuel Saez, The Optimal Income Taxation of Couples as a Multi-Dimensional Screening Problem, September 2007

2093 Michael Rauber and Heinrich W. Ursprung, Life Cycle and Cohort Productivity in Economic Research: The Case of Germany, September 2007

2094 David B. Audretsch, Oliver Falck and Stephan Heblich, It's All in Marshall: The Impact of External Economies on Regional Dynamics, September 2007

2095 Michael Binder and Christian J. Offermanns, International Investment Positions and Exchange Rate Dynamics: A Dynamic Panel Analysis, September 2007

2096 Louis N. Christofides and Amy Chen Peng, Real Wage Chronologies, September 2007

2097 Martin Kolmar and Andreas Wagener, Tax Competition with Formula Apportionment: The Interaction between Tax Base and Sharing Mechanism, September 2007

2098 Daniela Treutlein, What actually Happens to EU Directives in the Member States? - A Cross-Country Cross-Sector View on National Transposition Instruments, September 2007

2099 Emmanuel C. Mamatzakis, An Analysis of the Impact of Public Infrastructure on Productivity Performance of Mexican Industry, September 2007

2100 Gunther Schnabl and Andreas Hoffmann, Monetary Policy, Vagabonding Liquidity and Bursting Bubbles in New and Emerging Markets - An Overinvestment View, September 2007

2101 Panu Poutvaara, The Expansion of Higher Education and Time-Consistent Taxation, September 2007

2102 Marko Koethenbuerger and Ben Lockwood, Does Tax Competition Really Promote Growth?, September 2007

2103 M. Hashem Pesaran and Elisa Tosetti, Large Panels with Common Factors and Spatial Correlations, September 2007

2104 Laszlo Goerke and Marco Runkel, Tax Evasion and Competition, September 2007

2105 Scott Alan Carson, Slave Prices, Geography and Insolation in $19^{\text {th }}$ Century AfricanAmerican Stature, September 2007

2106 Wolfram F. Richter, Efficient Tax Policy Ranks Education Higher than Saving, October 2007 
2107 Jarko Fidrmuc and Roman Horváth, Volatility of Exchange Rates in Selected New EU Members: Evidence from Daily Data, October 2007

2108 Torben M. Andersen and Michael Svarer, Flexicurity - Labour Market Performance in Denmark, October 2007

2109 Jonathan P. Thomas and Tim Worrall, Limited Commitment Models of the Labor Market, October 2007

2110 Carlos Pestana Barros, Guglielmo Maria Caporale and Luis A. Gil-Alana, Identification of Segments of European Banks with a Latent Class Frontier Model, October 2007

2111 Felicitas Nowak-Lehmann D., Sebastian Vollmer and Immaculada Martínez-Zarzoso, Competitiveness - A Comparison of China and Mexico, October 2007

2112 Mark Mink, Jan P.A.M. Jacobs and Jakob de Haan, Measuring Synchronicity and Comovement of Business Cycles with an Application to the Euro Area, October 2007

2113 Ossip Hühnerbein and Tobias Seidel, Intra-regional Tax Competition and Economic Geography, October 2007

2114 Christian Keuschnigg, Exports, Foreign Direct Investment and the Costs of Corporate Taxation, October 2007

2115 Werner Bönte, Oliver Falck and Stephan Heblich, Demography and Innovative Entrepreneurship, October 2007

2116 Katrin Assenmacher-Wesche and M. Hashem Pesaran, Assessing Forecast Uncertainties in a VECX Model for Switzerland: An Exercise in Forecast Combination across Models and Observation Windows, October 2007

2117 Ben Lockwood, Voting, Lobbying, and the Decentralization Theorem, October 2007

2118 Andrea Ichino, Guido Schwerdt, Rudolf Winter-Ebmer and Josef Zweimüller, Too Old to Work, too Young to Retire?, October 2007

2119 Wolfgang Eggert, Tim Krieger and Volker Meier, Education, Unemployment and Migration, October 2007

2120 Stefan Napel and Mika Widgrén, The European Commission - Appointment, Preferences, and Institutional Relations, October 2007

2121 Bertil Holmlund and Martin Söderström, Estimating Income Responses to Tax Changes: A Dynamic Panel Data Approach, October 2007

2122 Doina Maria Radulescu, From Separate Accounting to Formula Apportionment: Analysis in a Dynamic Framework, October 2007

2123 Jelle Brouwer, Richard Paap and Jean-Marie Viaene, The Trade and FDI Effects of EMU Enlargement, October 2007 
2124 Kurt R. Brekke, Luigi Siciliani and Odd Rune Straume, Competition and Waiting Times in Hospital Markets, October 2007

2125 Alexis Direr, Flexible Life Annuities, October 2007

2126 Johannes Becker and Clemens Fuest, Quality versus Quantity - The Composition Effect of Corporate Taxation on Foreign Direct Investment, October 2007

2127 Balázs Égert, Real Convergence, Price Level Convergence and Inflation Differentials in Europe, October 2007

2128 Marko Koethenbuerger, Revisiting the "Decentralization Theorem" - On the Role of Externalities, October 2007

2129 Axel Dreher, Silvia Marchesi and James Raymond Vreeland, The Politics of IMF Forecasts, October 2007

2130 Andreas Knabe and Ronnie Schöb, Subsidizing Extra Jobs: Promoting Employment by Taming the Unions, October 2007

2131 Michel Beine and Bertrand Candelon, Liberalization and Stock Market Co-Movement between Emerging Economies, October 2007

2132 Dieter M. Urban, FDI Technology Spillovers and Wages, October 2007

2133 Valentina Bosetti, Carlo Carraro, Emanuele Massetti and Massimo Tavoni, Optimal Energy Investment and R\&D Strategies to Stabilise Greenhouse Gas Atmospheric Concentrations, October 2007

2134 David-Jan Jansen and Jakob de Haan, The Importance of Being Vigilant: Has ECB Communication Influenced Euro Area Inflation Expectations?, October 2007

2135 Oliver Falck, Heavyweights - The Impact of Large Businesses on Productivity Growth, October 2007

2136 Xavier Freixas and Bruno M. Parigi, Banking Regulation and Prompt Corrective Action, November 2007

2137 Jan K. Brueckner, Partial Fiscal Decentralization, November 2007

2138 Silvia Console Battilana, Uncovered Power: External Agenda Setting, Sophisticated Voting, and Transnational Lobbying, November 2007

2139 Alan J. Auerbach, Michael P. Devereux and Helen Simpson, Taxing Corporate Income, November 2007

2140 Lorenzo Cappellari, Paolo Ghinetti and Gilberto Turati, On Time and Money Donations, November 2007 
2141 Roel Beetsma and Heikki Oksanen, Pension Systems, Ageing and the Stability and Growth Pact, November 2007

2142 Hikaru Ogawa and David E. Wildasin, Think Locally, Act Locally: Spillovers, Spillbacks, and Efficient Decentralized Policymaking, November 2007

2143 Alessandro Cigno, A Theoretical Analysis of the Effects of Legislation on Marriage, Fertility, Domestic Division of Labour, and the Education of Children, November 2007

2144 Kai A. Konrad, Mobile Tax Base as a Global Common, November 2007

2145 Ola Kvaløy and Trond E. Olsen, The Rise of Individual Performance Pay, November 2007

2146 Guglielmo Maria Caporale, Yannis Georgellis, Nicholas Tsitsianis and Ya Ping Yin, Income and Happiness across Europe: Do Reference Values Matter?, November 2007

2147 Dan Anderberg, Tax Credits, Income Support and Partnership Decisions, November 2007

2148 Andreas Irmen and Rainer Klump, Factor Substitution, Income Distribution, and Growth in a Generalized Neoclassical Model, November 2007

2149 Lorenz Blume, Jens Müller and Stefan Voigt, The Economic Effects of Direct Democracy - A First Global Assessment, November 2007

2150 Axel Dreher, Pierre-Guillaume Méon and Friedrich Schneider, The Devil is in the Shadow - Do Institutions Affect Income and Productivity or only Official Income and Official Productivity?, November 2007

2151 Valentina Bosetti, Carlo Carraro, Emanuele Massetti and Massimo Tavoni, International Energy R\&D Spillovers and the Economics of Greenhouse Gas Atmospheric Stabilization, November 2007

2152 Balázs Égert and Dubravko Mihaljek, Determinants of House Prices in Central and Eastern Europe, November 2007

2153 Christa Hainz and Hendrik Hakenes, The Politician and his Banker, November 2007

2154 Josef Falkinger, Distribution and Use of Knowledge under the "Laws of the Web", December 2007

2155 Thorvaldur Gylfason and Eduard Hochreiter, Growing Apart? A Tale of Two Republics: Estonia and Georgia, December 2007

2156 Morris A. Davis and François Ortalo-Magné, Household Expenditures, Wages, Rents, December 2007 